\title{
Hétköznapi gyanakvás: életünk a paranoia
}

\author{
Janka Zoltán dr. \\ Szegedi Tudományegyetem, Általános Orvostudományi Kar, Pszichiátriai Klinika, Szeged
}

\begin{abstract}
A gyanakvó gondolkodás adott helyzetben hasznos és adaptációt segítő lehet, amelyet a világban előforduló események is visszaigazolnak. A paranoia kialakulásában szereplő tényezők közé pszichodinamikai (projekció), jelentőségtulajdonítási (salience attribution), neurobiológiai (dopamin), percepcióromlási (halláskárosodás), kulturálistársadalmi (kisebbség, álközösség), önértékelési (aggódás, depresszió, mánia), valamint kognitív (elhamarkodott következtetés) mechanizmusok tartozhatnak. A gondolkodás spektruma mentén az enyhétól a súlyosig különféle tartalommal előfordulhat túlzott aggodalmaskodás, fokozott jelentőségtulajdonítás, túlértékelt elképzelés, gyanakvás/bizalmatlanság, paranoid gondolat és kikristályosodott téveszme. Az elmúlt években intenzív kutatások indultak a szubklinikus paranoiditás felderítésére az átlagpopulációban. E célra kifejlesztett szúrômódszerekkel (paranoiaskálák, pszichometriai tesztek, virtuális valóság laboratórium) azt találták, hogy a lakosság körében meglehetősen gyakoriak a gyanakvó/bizalmatlan elképzelések, és ezek némelyike a betegpopulációban észlelt mértéket is elérheti. Az enyhén paranoid ideák nagyobb előfordulásától a súlyosabbak kisebb gyakoriságáig az egész hierarchikus jelenség egy 'paranoiapiramist' alkot. Az emberekben meghúzódó hétköznapi paranoid gondolkodás alapján megfogalmazható, hogy 'életünk a paranoia'. Orv. Hetil., 2016, 157(50), 1979-1988.
\end{abstract}

Kulcsszavak: paranoia, téveszme, gyanakvás, átlagpopuláció, szűrés

\section{Everyday suspicion: our life is delusional}

Suspicious thinking in given situations can be useful and helps the adaptation as events occurring in the world also corroborate this. Factors participating in the development of paranoia can be listed as psychodynamic (projection), salience attributional, neurobiological (dopamine), impaired perceptual (hearing loss), sociocultural (minority, pseudocommunity), self-esteem (worrying, depression, mania), and cognitive (jump-to-conclusion) mechanisms. Along the spectrum of thinking, from the mild to the severe, enhanced worrying, salience attribution, overvalued concepts, suspicion/mistrust, paranoid ideations, and crystallized delusions may occur with different contents. In recent years intensive research has been started to reveal the presence of subclinical paranoid thoughts in the general population. Applying various screening methods developed for this purpose (delusions inventories, psychometric tests, virtual reality laboratory) it has been found that suspicious/mistrustful ideations are fairly common in nonclinical samples and some of these are comparable to that seen in patient population. From the larger occurrence of milder forms to the smaller frequency of more severe delusional thoughts the whole hierarchical phenomenon can be described as a 'paranoia pyramid'. Based on this everyday paranoid thinking style lurking in people, it may well be that 'our life is delusional'.

Keywords: paranoia, delusion, suspiciousness, general population, screening

Janka, Z. [Everyday suspicion: our life is delusional]. Orv. Hetil., 2016, 157(50), 1979-1988.

(Beérkezett: 2016. szeptember 25.; elfogadva: 2016. október 20.)

Nyolcvan éve, hogy a Nature folyóiratban megjelent Selye korszakalkotó közleménye, amely világszerte végül is a stresszelméletet alapozta meg [1]. Selye egyik magya- rul megjelent könyvének címe 'Életünk és a stressz'. Ennek mintájára a világban uralkodó állapotokra és az emberiség larvált és mitigált formában jellemző paranoid 
gondolkodására nyugodtan alkalmazható a 'sejtés Selye után: életünk a paranoia' kifejezés (amint az utóbbit a közlemény címe is jelzi).

A téveszme (doxasma, delusio) olyan rögzült elgondolás, amelynek nincs valóságalapja és ellenáll minden megváltoztatásnak, még ha objektív és logikusan ellentmondó érvekkel és adatokkal szembesül is. A pszichózis biztos tünete. A paranoia $(\pi \alpha \rho \dot{\alpha}=$ para, mellett; voós = noos, elme) kifejezés egyik értelme a túlzott gyanakvás. Az enyhén paranoid jelleg és a bizarr téveszmés meggyőződés között széles a spektrum sok átmenettel és súlyossági fokozattal. Esetleg csak néhány paranoid személyiségjegy észlelhető vagy már paranoid személyiségzavar áll fenn, míg súlyos esetben a paranoid pszichózis betegsége, ahol a valóságtól elrugaszkodott téves állítások és abnormális okoskodások töltik ki a gondolkodást.

A gyanakvó/paranoid hozzáállásnak azonban evolúciós szempontból jelentősége van. Az állatvilágban sem célszerú a gazellának oroszlánnal barátkoznia, jobb az óvatosság. Embernél is a másokba vetett feltétlen bizalom (amely ideális és követendően helyes lenne) káros következményekkel járhat, ismerve a világban rejlő ez irányú veszélyeket.

\section{Hétköznapi gyanakvás}

Felvetődik a kérdés, hogy a hétköznapi életben megjelenhet-e gondolkodásunkban a gyanakvás vagy bizalmatlanság (akár kifejezett formában is)? Csak néhány példa, amely természetesen hosszan folytatható: Múködik-e az új helyen a bevált technika? Az érdem el nem ismerésekor: pikkel a fónök/tanár? Elvégezte-e a feladatot a munkatárs? Az étteremben nem számoltak-e többet? Illeszkedik-e a komputerek rendszere? Hüséges-e a partner? Maradt-e hiba az irományban? A tömegközlekedési eszközön van-e fertőzésveszély? A beteg-nyilvántartási rendszer valóban titoktartó? Biztonságos-e a bankkártyás fizetés? Kirabolják-e az üresen hagyott otthont? Plágium-e a szakdolgozat? Hibás-e az információforrás (könyv, internet)? Hátrahagyott hátizsák: mi lehet benne? Figyel-e a Nagy Testvér? Lehet-e hinni a hírnek? Van-e szakértelme/diplomája? Étkezés: milyen minőségű alapanyagból lehet a táplálék? Kijavítja-e a nyomda a jelzett hibát? E sorok írójában az alábbiak is felmerültek már: Nem lesz-e túlságosan polgárpukkasztó az operafelújítás rendezése? Átsütötték-e a bélszínt, amelyre a nyomatékos kérés szólt? Igaza van-e a kritikát alkalmazónak az adatokkal kapcsolatban?

Csak a legutolsó kérdésfelvetésre utalva, érdemes a kritikát is leellenőrizni (amennyiben adatokról van szó), nem biztos, hogy a kritizálónak van igaza, nem tehet róla, rossz forrásból készpénznek vette az információt (azaz: kételkedni kell a kritikával kapcsolatban is).

A felsorolt tételek inkább azt világítják meg, hogy az óvatosság, enyhe gyanakvás adott esetben nagyon is szolgálhatja az ember alkalmazkodását (társas és tárgyi) környezetéhez. Igen hosszú viszont az út a kontinuum (spektrum) mentén a túlzott aggodalmaskodáson, a fokozott jelentőségtulajdonításon, a túlértékelt gondolaton, a bizalmatlanság csíráján, a felsorolt enyhén gyanakvó felvetéseken és a közepes fokú paranoid elgondolásokon keresztül a valóságalapot nélkülöző, pszichotikus mélységü és mindenképpen betegségtünetként értelmezhető kikristályosodott paranoid téveszméig (doxasma).

Analógiaként a szúkszavúság-bőbeszédűség 'SzekeresJanka beszédkvantum-spektruma' említhető: az egyik póluson áll a görög peloponnészoszi félszigeten a lakóniaiak (fővárosa: Spárta) tömör válasza II. Fülöp macedóniai királynak, aki a legszörnyúbb fenyegetések sokaságát ígérte, ha nem adják meg magukat. A lakonikus válasz csak ennyi volt: „Ha.” A másik pólus a zaporozsjei kozákok saját nyelvükön a hódító és temérdek titulust felsoroló IV. Mohamed török szultánnak írt levele (válasz a megadás felszólítására), amely igen hosszú, cirkalmas, bátor hangvételü, helyenként rendkívül trágár írás. Az eseményt Repin festményben örökítette meg, Apollinaire versben, Glière szimfonikus múvet komponált róla, irodalmárok és történészek pedig a tartalmát és lingvisztikáját, nyelvi fordulatait elemzik részletesen [2].

\section{A paranoia kialakulásának tényezői}

A paranoia keletkezésében a különféle elméletek több tényező szerepét tartják lényegesnek.

a) A pszichodinamikus iskola az elhárító énvédő mechanizmusok közül a projekciót (mint legfontosabbat) és a reakcióképzést emeli ki. Freud, amikor Daniel Paul Schreber bíró önéletrajzi írását olvasta (magát a személyt nem vizsgálta), teóriájában ezeket szerepeltette, sőt a latens homoszexualitás feltételezett és vitatott elméletét körvonalazta a paranoia mögött [3]. A projekció (kivetítés) mechanizmusában az egyén elfojtott ösztönvilágának elfogadhatatlan impulzusait másokra vetíti ki, azaz másoknak tulajdonít olyan jegyeket, amelyek saját magában rejlenek, másokat ruház fel ilyen tulajdonságokkal.

b) A kóros jelentőségtulajdonítás (salience attribution) lényeges lehet az észlelések magyarázata sorában; az egyén a környezete vagy belső világa ingereiből, új jelenségeiból kiragad számára fontosat (amely másoknak vagy az átlagnak egyáltalán nem az), felfigyel bizonyos dolgokra és azt magára nézve meghatározónak érzi, ezen töpreng, rágódik. Jellemző a fenyegető ingerekre történő preferált figyelem, a latens gátlás csökkenése, valamint károsodott forrásmonitorozás: a belülról vagy kívülről fakadó élmény elkülönítésének zavara [4].

c) A jelentőségtulajdonítás mögött idegélettani folyamatok húzódhatnak meg. Neurobiológiai szempontból azt gondoljuk, hogy az agyi dopamin neurotranszmitter rendszer tölt be e tekintetben fontos szerepet [5], azaz annak szabályozatlan, inadekvát, kisiklott, kaotikus (túl) múködése [6] végül is téveszméig fokozódó abnormális állapotot eredményez. Ezt fejezi ki a szerző dopaminnal és paranoiával kapcsolatos limerickje: 


\section{Érthet ám tévesen mást valamin, \\ Ha kóros töltést ad a dopamin. \\ Gyanakvást fokoz, \\ Pszichózist okoz; \\ Veszélyes, mint szörfölni cunamin.}

\section{$(j z)$}

A teoretikus megfontolásokon túl a klinikai gyakorlat tapasztalatai alapján a téveszmés gondolkodás pszichofarmakológiai befolyásolására legeredményesebbek a dopaminrendszer aktivitását csökkentő (leginkább a receptorokat gátló) antipszichotikumok (1. ábra). Az természetesen más kérdés, hogy a paranoid személy általában anosognosiás az állapotára nézve, nincs betegségbelátása, azaz mindenki más tévedhet, de az ő állítása és elmélete igaz, amely meggyőződésből logikusan következik, hogy gyógyszert nehezen fogad el és annak bevételében együttmúködése minimális vagy rapszodikus.

d) Újabban a claustrum anatómiai régió szerepét vetették fel a téveszmés állapot esetleges biológiai hátterében. A claustrum (1) mint 'zenekari karmester', a szenzoros modalitások szinkronizálásában tölt be szerepet, emellett (2) koincidenciadetektor, valamint (3) agykérgi hálózatok átkapcsolója és (4) a szelektív figyelem modulálója [7]. Természetesen egyéb kutatások is intenzíven folynak. Az agyi aktivitás-kapcsolódási mintázat (ami funkcionális mágneses rezonanciás [fMRI-] eljárással mérhető) szubklinikus téveszmével (sőt annak súlyossági szintjével) is összefüggést mutatott szociális reagálást igénylő teszthelyzetben. E tekintetben a lateralis tempo-

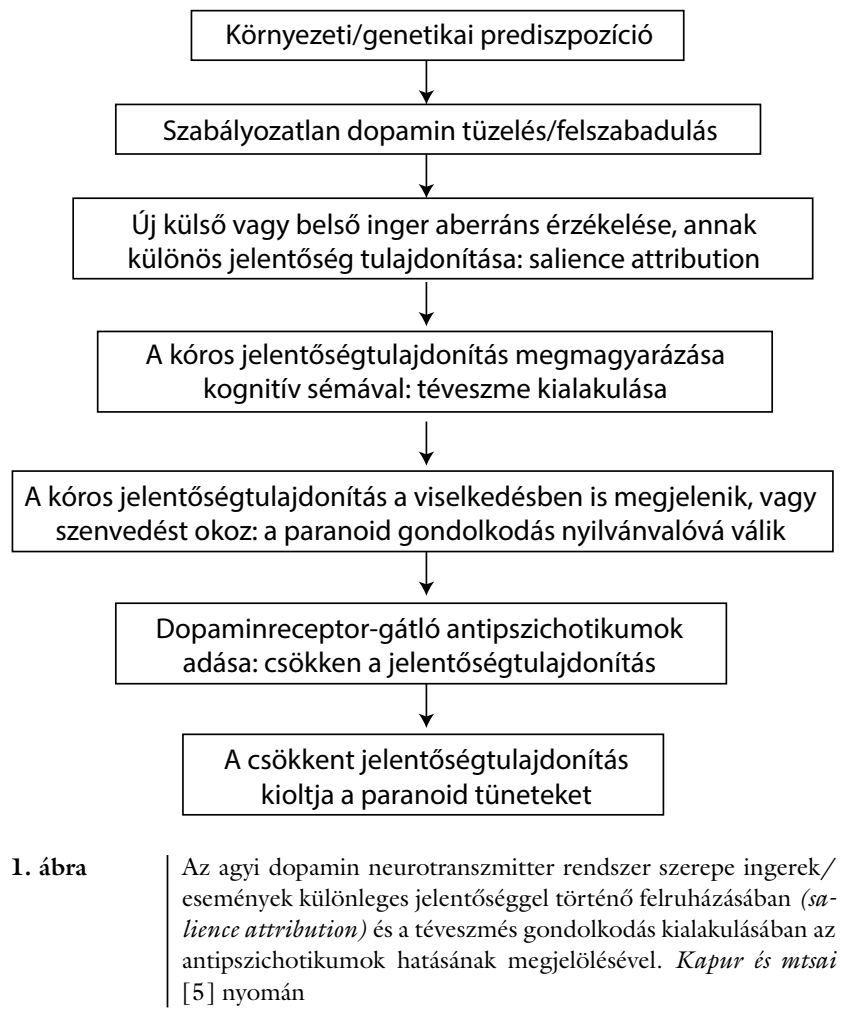

ralis kéreg, a hátsó gyrus cinguli és a medialis prefrontalis kéreg konnektivitása volt kitüntetett helyzetben [8].

e) A kognitív teóriák kísérletes pszichológiai vizsgálatokkal azt jelzik, hogy a téveszmés gondolkodásra hajlamos személy probabilisztikus döntéshozó helyzetben kevesebb adatot igényel következtetés levonására, néhány információ után elhamarkodott konklúzióra jut (jump-to-conclusion - JTC). Mindez speciálisan kifejlesztett tesztekkel igazolható, ahol bizonyos számú golyóhúzás után kell eldönteni, hogy az melyik konténerból származik (beads task) [9]. A közelmúlt metaelemzése $(n=2237)$ adatokat szolgáltat arra, hogy a fenti tesztben a döntés előtt kért gyöngyök (golyók) száma (adatgyűjtés) és a skálával megítélt téveszmés gondolkodás mértéke közötti összefüggés negatív korrelációt jelez, azaz a súlyosabb állapot kevesebb adatgyújtést feltételez a döntéshozatalhoz [10]. A gondolkodás és viselkedés visszaigazolása és megerősítése értelmezésében pedig torzító kognitív mechanizmusok (kognitív disztorziók) a jellemzőek.

f) A paranoid álközösség (pseudocommunity) elméletében Cameron [11] hét olyan helyzetet ír le, amely kedvez a téveszmés állapot kialakulásának. Ilyenek: 1. kegyetlen bánásmód, 2. szociális izoláció, 3. fokozott bizalmatlanság/gyanakvás, 4. irigység/féltékenység, 5 . önértékelést rontó szituációk, 6. saját hibáit másokban keresés, 7. a háttérben húzódó valódi okokon történő töprengés (ruminatio, őrlődés/rágódás).

Az irigység/féltékenység (Invidia) a hét fóbưn egyike, a középkorban is elítélték ezen emberi tulajdonságot. Az Invidia Dante 'Isteni színjáték' címú múve Purgatórium fejezete XVII. énekében, a Purgatórium beosztásában a Pokoltól számított II. körben szerepel mint a rossz szeretete. Alatta (a Pokolhoz közelebb) csak egy súlyosabb bűn van, a gőg, dölyfösség, mások lenézése (Superbia). Hieronymus Bosch asztallapra festett alkotásán ('A hét fóbû́n és a négy végső dolog', Prado múzeum, Madrid) is feltünik az Invidia ábrázolása a belső kör alakú táblakép egyik szegmensében, de további irodalmi/ múvészeti példák is fellelhetők erről [12].

g) A percepció romlása (például halláskárosodás) szintén tényező, hiszen fontos kommunikációs csatorna; kiesése kapcsán a viselkedés társas visszaigazolása sérül. A halláskárosodott személy például nem érti környezete beszélgetését (talán róla folyik?), ha mosolyognak, esetleg arra gondol, hogy ő lehet a mosolygás (tréfa/gúny) tárgya. Metaelemzések is igazolják az összefüggéseket [13].

h) Az önértékelés csökkenése [14] szintén lényeges lehet, a társas életben a biztos tájékozódást vesztő, saját értékeit minimalizáló, az értéktelenség hamis érzésével vergődő és aggódó/szorongó lélek jó táptalaj a téveszmés gondolkodás kifejlődésére. Az önértékelés/önbecsülés megromlása (az önbecsülés önbecsmérlésbe átcsapása) depresszióban különösen gyakori. A szerző praxisából megemlíthető eset: egy súlyosan depressziós középkorú nőbeteg letérdelve könyörgött, hogy jelent- 
sék fel ôt a rendőrségen és bíróságon, ítéljék el, mert fiatalabb korában bűnt követett el. Kiderült, mit tekintett 'bünnek': azt, hogy gyermekéhez időnként pár órára pótmamát fogadott. Ez már nyilván extrém pszichotikus mélységű torzulása a gondolkodásnak, ahol az önértékelés-zavar bûnösségi téveszméig fokozódott. Tanulmányok szerint a depresszió és kognitív torzítás előre jelezték a paranoid gondolkodást, de nem az okfejtési/ érvelési stílust [9]. Az is megfogalmazható, hogy az 'állandó aggódás, aggodalmaskodás paranoiához vezethet'. A hangulati pólus másik véglete, a mánia, jellegzetesen ellentétes (megalomán, grandiózus) tartalmú téveszmés ideák kialakulását eredményezheti, azaz a személy által megélt különleges képességek, speciális tudás, hatalmasságokhoz való kapcsolatok koncepciója jelenik meg a viselkedésben. Szintén a praxisból: az egyik hentes foglalkozású, bipoláris kedélyzavaros beteg a mániás szakában rendszeresen azt hangoztatta, hogy pontosan meg tudja becsülni az emberek súlyát és magasságát. Amikor erre sor került (az orvostanhallgatók nagyon kedvelték), a megítélendő alany meglepetésére a beteg odalépett hozzá, megfogta a karját, vállát, felmérte az izomtömeget, a csontok vastagságát és viszonylagos pontossággal meg is mondta az eredményt (belátható a hentes foglalkozással való összefüggés). Az euthymiás vagy depressziós szakában viszont mindezen 'képessége' eltünt.

i) A társadalomban valamilyen kisebbségi lét (illetve az ezzel sokszor együtt járó stigmatizáció és diszkrimináció) és a paranoid gondolkodás kifejlődésének összefüggésére is vannak adatok. Tünetmentes holland átlagpopulációban ( $\mathrm{n}=4076$ fó) a megélt (észlelt, érzékelt) diszkrimináció differenciált megítélését mérték fel, valamint pszichotikus tünetek (doxasma, hallucináció) megjelenését. Hároméves követésben a téveszmés gondolat 0,5\%-ban fordult elő azon személyekben, akik nem számoltak be diszkriminációról, 2,7\%-ban azoknál, akiket több mint egy területen ért diszkrimináció, illetve 0,9\%ban azokban, akiket csak egy területen. A szubjektíven megélt diszkrimináció tehát paranoid gondolkodást indukálhat és a kisebbségekben észlelt magasabb pszichózisarány egyik tényezője lehet [15]. Természetesen mindez megfordítva is igaz, azaz a paranoid gondolkodás stigmatizál, amint azt amerikai $(\mathrm{n}=8990)$ és tajvani kínai $(\mathrm{n}=524)$ populációkban észlelték [16, 17].

A különféle helyzetek és tényezők összeadódhatnak. Ha az ezek kombinációjából eredő frusztráció meghaladja a személy tűrőképességét, akkor visszahúzódik, szorongó lesz, realizálja, hogy valami baj van és magyarázatot keres. A megoldás a téveszme (rendszer) kikristályosodása, valós vagy elképzelt embereknek (ágenseknek) rossz szándék tulajdonítása. Az üldöztetéses tévkoncepció kialakulásában szereplő kognitív és emocionális pszichológiai folyamatokat mutatja be a 2. ábra [18].

A téveszme kialakulása dinamikájában Conrad [19] az alábbi (görög kifejezésekkel ellátott) stádiumokat különítette el: 1. Trema, a remegés, amikor az egyén nem

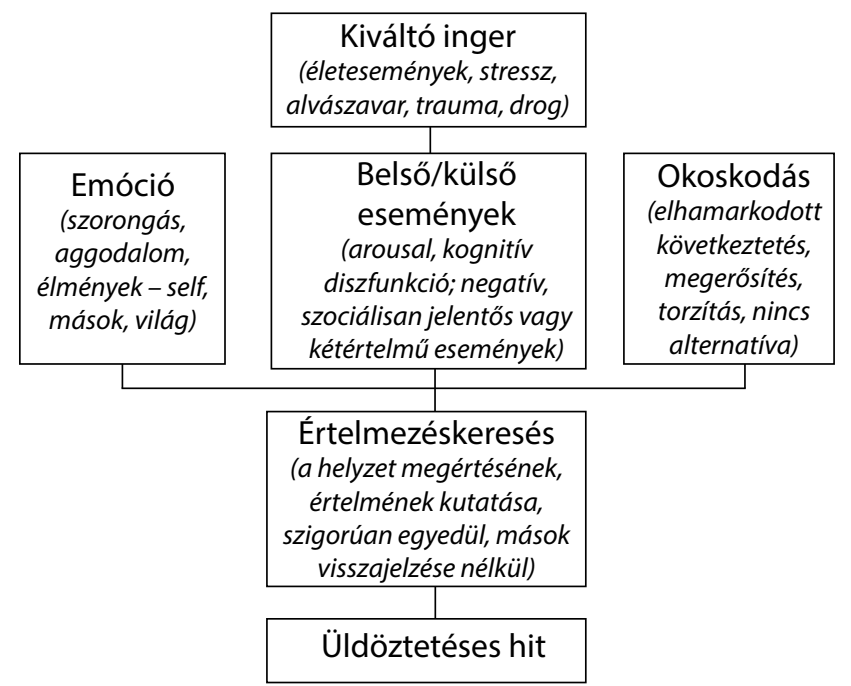

2. ábra Üldöztetéses, téveszmés meggyőződés kifejlődésének dinamikájában szereplő pszichológiai tényezók a kiváltó ingerekkel és a belső/külső eseményekkel összefüggésben. Garety és Freeman [18] nyomán

érti, hogy mi van körülötte, fenyegetettséget érez, ideges, szorong, vívódik; 2 . Apophenia, a nyilvánvalóvá válás, amikor a vívódás feloldódik, a magyarázat megszületett (amely hamis), kóros jelentőséget tulajdonít tipikusan külső ágens(ek)nek; 3. Anastropha, a megfordulás, a jellegzetesen befelé fordulás, amikor az egyén a téveszméjével beköltözik saját zárt világába, természetesen gyanakvó kitekintéssel a külső környezetre.

A téveszmés gondolkodás tartalma és mértéke az esetleg akár hihető elképzeléseken (nem ismerik el tudását, mert pikkelnek rá) át a bizarr doxasmákig terjedhet és a kulturális közfelfogásnak függvénye. Esetleg csak az adott kultúrkörben (vö. következő két fejezet) bizarrnak számító jelleg hívja fel a figyelmet arra, hogy az illető feltehetően pszichotikus (például passzív befolyásoltatásos doxasma: gondolatainak külső erők által történő elvonása, visszaadása, sugárzása TV-ben, rádióban, közreadása újságban/interneten, cselekedeteinek, mozdulatainak idegenek által való irányítása; az ellenkezője is lehet, hogy ő irányít másokat [aktív befolyásolás]). Egyszer valaki azzal jelentkezett, hogy ufóval érkezett éppen, a közeli téren landolt, másokat képes irányítani és a világot jött megtéríteni. Az ufóban hisznek azért néhányan szerte a világban, de az adott helyzetben mégis kissé bizarrnak hatott ezen állítás (anélkül, hogy a téren a leszállt ufót megnéztük volna).

Jelen közleménynek nem tárgya a klinikumban előforduló paranoid állapotok, specifikus téveszme- (doxasma-) formák és szindrómák részletezése; annak néhány szerzői vagy kulturális eredetű névvel ellátott tömör listája táblázatban látható (1. táblázat). A ritka pszichiátriai tünetekről és szindrómákról Tényi [20] könyvében találhatók leírások. 
\begin{tabular}{l|l} 
1. táblázat & $\begin{array}{l}\text { Specifikus paranoiaformák, néhány szerzői vagy kulturális erede } \\
\text { tû́ névvel (mint szindróma) }\end{array}$
\end{tabular}

\begin{tabular}{|c|c|c|}
\hline Doxasmatípus & Szindróma & A téveszme rövid leírása \\
\hline Megalomán & & $\begin{array}{l}\text { Grandiozitás, megnövekedett } \\
\text { képesség, tudás }\end{array}$ \\
\hline Erotomán & De Clérambault & $\begin{array}{l}\text { Fontos személy vagy híresség } \\
\text { szerelmes belé }\end{array}$ \\
\hline Genealógiai & & $\begin{array}{l}\text { Különleges származás, } \\
\text { sokszor híres személytől }\end{array}$ \\
\hline $\begin{array}{l}\text { Aktív } \\
\text { befolyásolásos }\end{array}$ & & $\begin{array}{l}\text { Mások gondolatainak/ } \\
\text { cselekedeteinek kontrollja }\end{array}$ \\
\hline Inventatoros & & $\begin{array}{l}\text { Feltalálások, különleges, } \\
\text { értékes találmányok }\end{array}$ \\
\hline Féltékenységi & Othello & $\begin{array}{l}\text { A partner hűtlenségéről } \\
\text { kialakított téveszme }\end{array}$ \\
\hline Vonatkoztatási & & $\begin{array}{l}\text { Mindent magára vesz, } \\
\text { emberek róla beszélnek }\end{array}$ \\
\hline Persecutoros & & $\begin{array}{l}\text { Üldöztetés, fenyegetettség, } \\
\text { ártalom célpontja }\end{array}$ \\
\hline Querulans & Koblhaas & $\begin{array}{l}\text { A kóros igazságkeresés } \\
\text { perlekedő viselkedése }\end{array}$ \\
\hline $\begin{array}{l}\text { Passzív } \\
\text { befolyásoltatásos }\end{array}$ & & $\begin{array}{l}\text { Gondolatait/cselekedeteit } \\
\text { külső erók irányítják }\end{array}$ \\
\hline Microman & & $\begin{array}{l}\text { Önkicsinylés, elszegényedés, } \\
\text { bűnösségérzés }\end{array}$ \\
\hline Szomatikus & Cotard & $\begin{array}{l}\text { Testi nihilizmus, szervek } \\
\text { sincsenek, halott }\end{array}$ \\
\hline Bőrférgességi & Ekbom & $\begin{array}{l}\text { Bőrét elárasztó férgek, } \\
\text { rovarok (bőrgyógyászat) }\end{array}$ \\
\hline Hypoidentificatio & Capgras & $\begin{array}{l}\text { Ismerőst hasonmás, csaló, } \\
\text { szélhámos helyettesít }\end{array}$ \\
\hline Hyperidentificatio & Fregoli & $\begin{array}{l}\text { Idegen személy ismerősként } \\
\text { történő azonosítása }\end{array}$ \\
\hline Lycantropia & & $\begin{array}{l}\text { Kutyának vagy farkasnak } \\
\text { képzeli magát }\end{array}$ \\
\hline Heautoscopia & & $\begin{array}{l}\text { Egy távolságból kívülrőll látja } \\
\text { saját magát }\end{array}$ \\
\hline $\begin{array}{l}\text { Reduplicativ } \\
\text { paramnesia }\end{array}$ & & $\begin{array}{l}\text { Két vagy több helyen van } \\
\text { egyszerre }\end{array}$ \\
\hline $\begin{array}{l}\text { Self- } \\
\text { misidentificatio }\end{array}$ & & $\begin{array}{l}\text { Tükörben saját maga téves } \\
\text { azonosítása }\end{array}$ \\
\hline Indukált & Folie à deux & $\begin{array}{l}\text { Más téveszméjének } \\
\text { elfogadása és hangoztatása }\end{array}$ \\
\hline
\end{tabular}

Az Othello történet (Shakespeare-dráma, amelynek operafeldolgozásai is ismertek: Verdi és Rossini) nem szorul magyarázatra. De Clérambault, Cotard, Ekbom, Capgras a tünetcsoportokat leíró orvosok voltak. Koblhaas Mihály egy kissé elfeledett, de nagy német író, Heinrich von Kleist (1771-1811) kisregényének címe (Michael Kohlhaas) és fószereplője. A mű pszichiátriai feldolgozása megtalálható a szakirodalomban [21]. Leopoldo Fregoli (1867-1936) olasz származású híres színész volt azon különleges képességgel, hogy pillanatok alatt tudott átöltözni és magát is átváltoztatni; a színpad egyik oldalán kivonult és rövid idő alatt más alakot öltve jött vissza. A színészt szerte a világban ismerték és ünnepelték, Budapesten is járt. A szindróma elnevezés alapját az adja, hogy ugyanazon személy más-más alakban képes magát álcázni. A folie à deux két személy megosztott téveszméjére utal, de több is lehetséges (trois, quatre, cinq, douze), kissé utalva a tréfás népi mondásra: egy bolond százat csinál.

\section{Szokatlan viselkedés törzsi társadalmakban}

A paranoid/gyanakvó viselkedés kulturálisan is megalapozott lehet. Zárt társadalmakban, diktatúrákban a paranoid álközösség kapcsán felsorolt tényezők közül jó pár jelen van, és a gyanakvás széles körü, mivel van is reális alapja. Néhány politikusra és államfőre is jellemzőek voltak ilyen személyiségjegyek, ami időnként népirtáshoz vezetett (például Idi Amin, Uganda, de lehet sok egyéb példát is említeni). Törzsi társadalmakban kulturális antropológiai kutatásokkal hasonlóakat találtak. A leírások szerint Pápua Új-Guineától keletre, a Dobu szigetcsoport tagjaira irigység, féltékenység, sértődékenység, erősen gyanakvó beállítódás volt jellemző. Lopás, csalás, hazudozás, mások sértése teljesen elfogadott volt, sőt ez adta az illetőnek meg a státuszához méltó presztízst. Másoktól csak gonosz szándékot és rosszat reméltek, ami ellen varázslattal és mágiával próbáltak védekezni. Az ellenséges viszony férj és feleség között is fennállt. Felváltva egymás falujában éltek és ott egymást megaláztatásnak és bántalmazásoknak tették ki.

Más népcsoportokra is különleges szokások voltak jellemzőek. Kanada nyugati partjainál például a kwakiutl indiánok körében a klánokba tömörült nép tagjai rendkívüli módon tekintették a rangot és különleges szokásokkal tudtak ennek eleget tenni vagy ezen változtatni. A jómódú törzsi arisztokrácia a felhalmozódott vagyont ceremoniális fesztiválok (úgynevezett potlatch) keretében elajándékozta vagy elpusztította. A meghívott szomszédos klán törzsfónökével versenyben is akár; a presztízst az jelentette, ha minél több tárgyat tud elajándékozni vagy elpusztítani. A merôben más beállítódású európai telepeseknek és misszionáriusoknak fel is túnt ez a szokás, amely ellentétben állt az úgynevezett civilizált életformával (amely inkább a vagyon felhalmozása), és a XIX. század második felében mind Kanadában, mind az Egyesült Államokban be is tiltották [22, 23].

A családszerkezetben a férfi-női szociális szerepek megfordulását figyelték meg Pápua Új-Guinea Sepik régiójában egyes törzseknél (tchambuli, most chambri). A nők voltak a családfők és domináns helyzetben, ők teremtették elő a megélhetés feltételeit, vitték a kereskedelmet/üzletet, vadásztak, sőt a szexuális közeledést is ők kezdeményezték. A férfiak ugyanakkor alávetettségben behódolva otthon ültek, vitték a háztartást, békésen beszélgettek, pletykáltak, szeretettel nevelték a gyermekeket, sminkkel is díszesen ellátták magukat és a táncot is kedvelték. Ebben a régióban az arapesh törzs tagjai mindkét nemére viszont ez a békés, szelíd, gyengéd magatartás volt jellemző, ami a gyermeknevelésben is a nők és férfiak között a feladatok együttes, kooperatív ellátását jelentette. Ugyanakkor, a mundugumor (most biwat) törzs férfijaira és nőire is a maszkulin viselkedés volt jellemző, sőt a vad, kegyetlen, drasztikus módszereket használó, agresszív megnyilvánulások is, ahol a gyerme- 
kek teljes elhanyagolása, magára hagyása dominált (akik természetesen a minta másolásával hasonló felnőttekké fejlődtek) $[23,24]$.

\section{Kultúraspecifikus pszichiátriai szindrómák}

Bizonyos földrajzi régiókban és társadalmakban a szokatlanságon túl kifejezetten pszichotikus, a valóság tesztelésének súlyos zavarával járó különleges paranoid (vagy hiszteroid, disszociatív, fóbiás) állapotok léphetnek fel, amelyek valamelyest jellemzőek arra a népcsoportra és kultúrára. A sajátos viszonyokat nem ismerő idegen értetlenül állhat a magyarázhatatlannak tűnő viselkedés láttán, míg a helyieknek akár természetesnek is tünhet. Sajnálatosan azonban egy-kettő az egész világon előfordul, mint például az amok, amely maláj szó (onnan is ered), az érintett (férfi) vad dühkitöréses állapotában válogatás nélkül pusztítja környezetét és homicídiumot követhet el (az ismert ámokfutás). A bouffée délirante hirtelen fellépő átmeneti pszichotikus állapot agresszióval, agitációval, konfúzióval, paranoid gondolatokkal és hallucinációval (Nyugat-Afrika, Haiti). A voodoo gonosz erók által való megszállottságot jelent, Afrikából terjedt szét, főként a karibi térségre (például Haiti, voodoo ceremóniák). A susto intenzív félelem természetfeletti erőktől Latin-Amerikában, a ghost sickness amerikai navajo indiánok körében az elhunytak szellemétől való megszállottság hite testi-lelki tünetekkel (az elhunyt nem kapott megfelelő temetést, ezáltal itt maradt, hogy az élőket kínozza), a wibtigo (windigo) kanadai indiánok körében attól való rettegés, hogy az illető hatalmas kannibál szörnnyé változik és emberi húst fog felfalni. Az ode-ori (Nigéria) fejben mocorgó paraziták és melegség érzése gonosz szellemektól való paranoid félelemmel. Az ufufuyane hajadonokban fellépő, visszautasított szeretőtől kapott varázsitalnak vagy gonosz szellemnek tulajdonított transzállapot bénulással, neologismák emlegetésével, sokszor éjszakai szexuális tartalmú rémálmokkal Kenyában és Dél-Afrikában. A taijin kyofusho szindróma (antropophobia, Japán) extrém félelem attól, hogy az egyén testi adottságaival, külsejével, szagával másoknak kellemetlenséget okoz, míg a pa-leng (frigophobia, Tajvan, Délkelet-Ázsia) a hidegtől való rettegés annak ellenére, hogy a környezet próbálja az ellenkezőjéről meggyőzni. A dhat indiai férfiakban a sperma vizeletbe ürülésének és ezáltal a vitális energia súlyos elvesztéséből fakadó teljes legyengülés hite. (Ốsi hindu elképzelés szerint 40 vércseppből keletkezik 1 csepp csontvelö, illetve 40 csepp csontvelő képez l csepp spermát.) A koro a férfi nemi szerv zsugorodásának, annak hasüregbe történő felhúzódásának és ezáltal az elpusztulásnak rettegett ideája Dél-Kínában (nőkben a vulvára és mellbimbókra vonatkozik mindez), emiatt a nemi szerv megragadásának kényszere annak védelme céljából. A latah akaratlan viselkedésutánzási állapot (beszédben: echolalia, mozgásban: echopraxia) Malajziában és Indonéziában, a Puerto Rico-i szindróma változatos pszichomotorium paranoid ideákkal, regresszióval, disszociációval, automutilációval és agresszióval, míg a piblokto eszkimó nók hiszteroid sikoltozása ruhadarabjaik ledobálásával és meztelenül rohangálásával a havon/jégen a dermesztő hideg ellenére. A mal de ojo (gonoszság a szemből, gonosz szem) viszont ősidők óta szerte a világban elterjedt hit a különféle népcsoportokban (számtalan nyelvben ott van a megfelelője, nálunk szemmel verés), amely ellen különféle amulettekkel/talizmánokkal, kézjelekkel vagy 'gyógymódokkal' védekeztek $[25,26]$.

\section{A paranoiditás lakossági szűróvizsgálatai}

Strauss [27] azt feltételezte, hogy a téveszmék (és hallucinációk) egy kontinuum mentén különféle súlyossági dimenzióként képzelhetők el, az erős meggyőződéstől kezdve a túlértékelt gondolaton való rágódáson/őrlődésen át egészen a logikailag megmagyarázhatatlan téveszméig.

A lakosság körében a mindennapokban előforduló paranoid gondolkodás szürésére az elmúlt években vizsgálatok indultak, a kezdeti lépések Angliában és Franciaországban történtek. A téveszmés elképzelések gyakran rejtőzködő, eltitkoló viselkedéssel járnak (disszimuláció), tehát a valóság kiderítése sokszor igen nehéz.

Egy nagyobb pszichiátriai kérdőívre (Present State Examination) alapozva először egy 40 tételes kérdőív kifejlesztésére került sor, amit 21 tételre rövidítettek (PDI, Peters et al. Delusions Inventory). Egészséges személyeket ( $\mathrm{n}=444$ ) és téveszmés tünetcsoportot mutató, osztályon fekvő betegeket ( $\mathrm{n}=33$ ) vizsgálva azt találták, hogy bár a betegek magasabb pontszámot mutattak a skálán, meglepő módon az egyes tételeket viszont 4-ből több mint 1 egészséges egyén magára nézve igaznak érezte. Jelentős átfedés mutatkozott a két csoport (egészséges és beteg) között, sőt az egészséges felnőttek 11\%-a magasabb pontszámot mutatott, mint a betegcsoport átlaga $[28,29]$.

A PDI-21-et használva Bordeaux-ban háziorvosi ellátás keretében $(\mathrm{n}=790)$ az életkorral negatív összefüggést találtak: a fiatalabbak magasabb pontszámai az üldöztetés, gondolatzavar, grandiozitás és paranormális hit delusiv dimenzióiban tûntek fel, míg a religiozitás pozitív életkori korrelációt mutatott. Felvetették, hogy fiatal felnőttkorban az idegfejlődési kórélettani tényezők miatt esendőség áll fenn pszichózis kifejlődésére [30, 31]. Hasonló felméréseket spanyol, svéd és ugandai lakossági mintákon is végeztek. Spanyolországban $(\mathrm{n}=365)$ a PDI-21 kérdőív 7 faktorából 5 negatív korrelációban állt az életkorral, a nók magasabb pontszámot mutattak a mágikus gondolkodás tételében, illetve az alacsonyabb iskolai végzettség ezzel és a befolyásoltatásos élmények faktoraival mutatott korrelációt [32].

Svédországban 1420 idős lakos körében felmérést végezve, paranoid gondolat a minta 6,3\%-ában adódott, amely kifejezettebb volt a kognitív diszfunkciót mutatókban $(\mathrm{n}=381,12,1 \%)$ az e téren jól funkcionálókhoz 
képest $(\mathrm{n}=1039,2,6 \%)$. A kognitív faktoron túl az alábbi tényezők szerepe volt még szignifikáns: elvált, nő, depressziós, pszichotróp szert szedő, barát vagy látogató nélküli, közösségi ellátásra szoruló, bevándorló. Amint az várható volt, a szociális izoláció esetén nagyobb paranoia mutatkozott [33].

Ugandában, egy dél-nyugati régióban fiatal felnőtt populációban (a kerület fóvárosa és 3 falu) a PDI-2l-es kérdőívet használva Európához képest a delusiv gondolatok és a hozzá kapcsolódó distressz, ruminatio, meggyőződés nagyobb mértéke volt jellemző. A magasabb paranoia-pontszám az alacsonyabb életkorral és a városi léttel függött össze; az utóbbi hatása kifejezettebb volt a magasabb iskolázottságúaknál [34].

Összefoglaló tanulmány [35] jelzi, hogy a felmérések adatai szerint átlagpopulációban tartalomtól függően körülbelül 1-3\%-ban klinikai szintet elérő súlyos, míg 5-6\%-ban kevésbé súlyos téveszmék detektálhatók, 1012\%-os gyakorisággal pedig rendszeresen előfordulnak delusiv gondolatok a nem klinikai lakossági mintákban.

Iránban (Dél-Teherán, $\mathrm{n}=2158$ ) lakossági szüréskor a paranoid tünetek gyakoriságát kapták, és a nemzetközi adatokhoz képest a szerzők szerint azon nem várt eredményt, hogy a paranoia súlyosabb formában jelentkezett a nők és a magasabb végzettségúek körében. (Megjegyzés: Mindez azért nem annyira meglepő a hely társadalmi-vallási-kulturális berendezkedését ismerve.) A pszichotikus tünetek a stresszteli életeseményekkel összefüggést mutattak [36]. Lengyelországban 421 lakos körében (76,7\% nő, átlagéletkor: 24,2 év) a PDI 40 tételes lengyel verzióját használva a PDI-40 átlaga 12,5 pont (0-34) volt, és a 40 szokatlan gondolatból átlag 31,3\% előfordulását észlelték (0-85\% tartomány). A leggyakrabban megerősített tétel a következő volt: 'az emberek kétértelmú megjegyzéseket tesznek' (79,8\%). A tartalomtól is függóen 2-80\%-ban fordultak elő paranoid gondolatok a vizsgált lengyel populációban [37].

\section{Paranoiditás egyetemi hallgatók körében}

Az Egyesült Államok Louisiana Állami Egyetemének diákjai körében $(\mathrm{n}=193)$ pszichológiai tesztek (paranoia, depresszió, szociális szorongás, attribúciós stílus, önértékelés) kitöltetésével azt találták, hogy a paranoid gondolkodás nagyobb mértékével a súlyosabb depressziós hangulat, fokozott szociális szorongás és elkerülő viselkedés, a közösségi megítéléstől való nagyobb félelem és az alacsonyabb önértékelési szint korrelált, míg a paranoiditás az attribúciós stílussal nem mutatott összefüggést ezen nem klinikai hallgatói csoportban [38].

Angliában (Exeter) diákpopulációban $(\mathrm{n}=324)$ a személyes érzések kognitív, magatartási és affektív komponenseit skálákkal (Fenigstein \& Vanable Paranoia Skála, Rosenberg Önértékelési Skála) elemezve 153 fő számolt be paranoiás élményről, amely kifejezetten tervszerú ártó szándékról szólt. Ezen csoport pontszáma magasabb volt a paranoiaskálán, mint a többieké, és a súlyosabb paranoid gondolkodás alacsonyabb önértékeléssel járt együtt. A szerzők úgy konkludáltak, hogy a paranoia közönséges és gyakori emberi élmény - a normális és abnormális viselkedés kontinuuma [39].

Spanyolország két egyetemén (La Rioja, Oviedo) a PDI-21 kérdőívvel 660 egyetemi hallgató körében (férfi: 29,5\%, átlagéletkor: 20,3 év) a PDI-21-értékek átlaga 4,3 pontnak adódott (férfi: 4,9, nő: 4,1), valamint nagy százalékban magas PDI-pontszámot találtak (29,8\% >5 pont, $11,4 \%>7$ pont). A paranoid gondolkodás tehát gyakorinak bizonyult, és szorongással, valamint negatív affektussal korrelált [40].

\section{Multidimenzionális megközelítések}

Paranoid gondolatok multidimenzionális pszichológiai elemzését 6 kérdőív segítségével nem klinikai populációban ( $\mathrm{n}=1202$ fó) azt kapták, hogy a csoport körülbelül egyharmadában paranoid gondolatok voltak jelen. A súlyosabb paranoiaszintet az alábbiak jellemezték: alávetett társadalmi helyzet, alacsonyabb státusz, emocionális vagy elkerülő megküzdés, izoláció, tétlenség, tehetetlenség és depresszió érzése. A Paranoia Skála 18 tételét (2. táblázat) megerôsítő vélemények eloszlása átlagpopulációban exponenciális görbét mutatott [41].

Amint egy torontói elemzés jelzi, önkéntes egészséges személyekben ( $\mathrm{n}=121)$ a pszichotesztekkel igazolt kognitív torzítások (valószínúségi okoskodásban gyors döntés, jump-to-conclusion - JTC), gyors lezárás, az abszurd vagy valószínútlen interpretációk plauzibilisként való el\begin{tabular}{l|l} 
2. táblázat & $\begin{array}{l}\text { Paranoid gondolkodás szürésére összeállított kijelentések } 18 \text { té- } \\
\text { teles listája [41] }\end{array}$
\end{tabular}

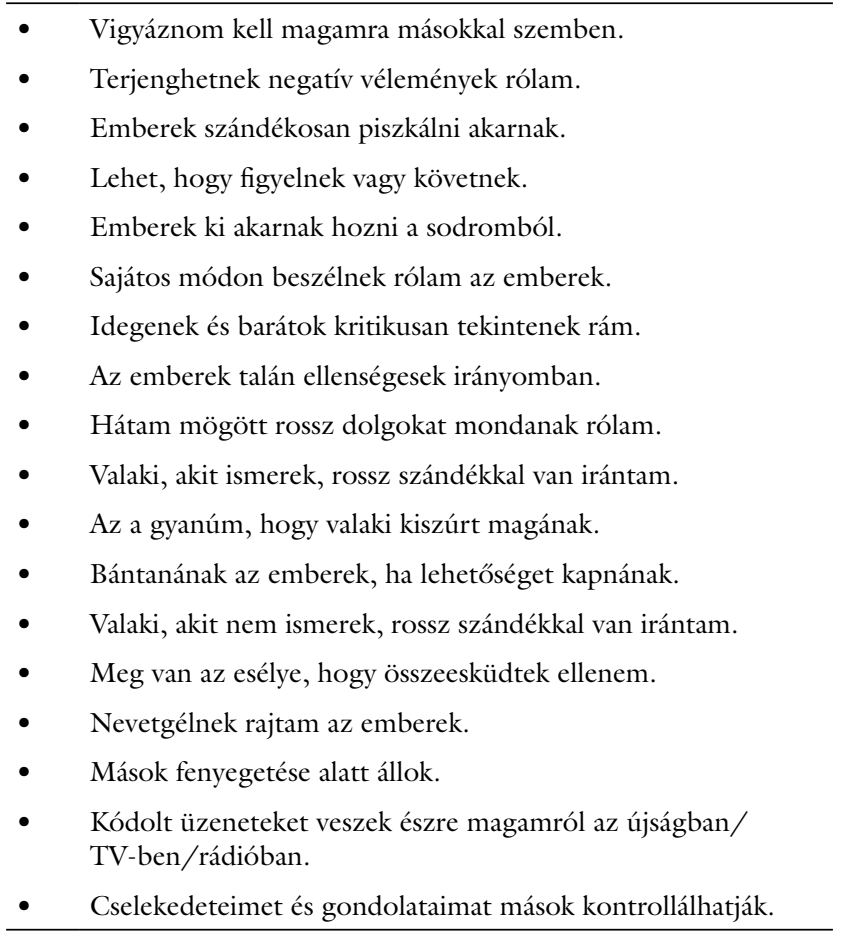


fogadása) szignifikánsan összefügg a szubklinikus (egészséges populáció) paranoid gondolkodással (PDI-skála). Természetesen ezen kognitív torzítások sokkal enyhébb formában jelennek meg, mint a doxasmát mutató tipikus betegeknél, viszont szerepet játszanak a téveszmék kialakulásában, mintegy közös utat (common pathway) képeznek az egészséges és pszichiátriai betegnek minősülő személyekben egyaránt [42].

Az öröklődési hajlam paranoiditáshoz való hozzájárulását megvilágító érdekes megfigyelés, hogy a 21 tételes PDI-t anyák $(\mathrm{n}=2861)$ és felnőtt gyermekeik $(\mathrm{n}=3079)$ körében kitöltetve a PDI-érték átlag 3,6 pontnak adódott anyáknál és 5,0-nek gyermekeiknél. A heritabilitas értéke 0,35 volt (az átlag standard hibája: 0,04); a variancia több mint egyharmadát öröklődési tényezők képezték, így felmerült, mint endofenotípus-vizsgálati lehetőség [43].

Walesben új skálát dolgoztak ki (Cardiff Beliefs Questionnaire - $C B Q$ ), amely a felfogásokban szélesebb tartományt ölelt fel a bizarr és nem bizarr téveszmétől a paranormális, vallási, általános politikai nézeteken át a szociális meggyőződésekig. A téveszmeszerü elképzelések (delusion-like beliefs - DLB) előfordulásának szűrését 1000 lakossági résztvevőnél végezték el, akiknek 39\%-a jelzett legalább 1 erős fokú DLB-t, 25\%-a legalább 1 erôs fokú bizarr téveszmét és 76\%-a pedig, ha az enyhe fokozatokat is számításba vették. Véleményük szerint téveszmeszerű gondolkodás gyakori az átlagpopulációban, és a pszichózis kontinuum jellegére utal [44].

A lakosság körében végzett szürővizsgálatok adatai azt jelzik, hogy a paranoid gondolkodás rejtett vagy nyilvánvaló formájában gyakori előfordulást mutat az átlagpopulációban, amire egy spektrumhierarchia jellemző: a halvány szorongásos aggodalmaktól az egyre kifejezettebb fenyegetettség érzéséig terjed. Az enyhén gyanakvó gondolatok szélesebb körben, míg a súlyosbodó változatok egyre keskenyebb körben jelennek meg a populációban, egyfajta hierarchikus elrendeződést mutatva ('paranoiapiramis', 3. ábra).

\section{Vizsgálatok virtuális valóság laboratóriumban}

Angliai kutatók virtuális valóság laboratóriumot alakítottak ki, ahol valós élethelyzeteket (például metrón [underground] utazás) tudnak szimulálni és a vizsgálati személyek paranoid elgondolásait, fenyegetettségérzését, valamint egyéb pszichológiai reakcióit tudják tesztelni. A toborzott 200 lakossági személy közül ezen kísérleti felállásban a többség számára a szimulált metrón utazásban megjelenő karakterek semlegesnek vagy inkább barátságosnak tüntek. Ugyanakkor egy szignifikáns kisebbség gyanakvó, bizalmatlan megnyilvánulásokat mutatott. A paranoid reakciókat az alábbi tényezők jelezték egyértelmúen előre: szorongás, aggodalmaskodás, percepciós anomáliák és kognitív rugalmatlanság. A tanulmány jelentősége, hogy ha nem is valóságos élethelyzetben tesz-

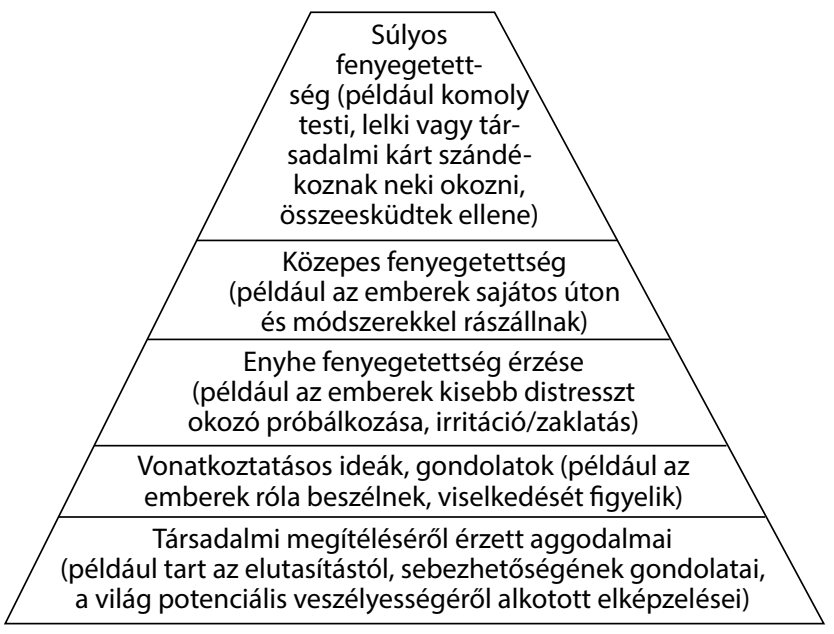

3. ábra

Az átlagpopulációban elóforduló paranoid/persecutoros gon dolkodás piramisként való ábrázolása a gyakoribb enyhe elképzelésektól és aggodalmaktól a ritkábban megjelenő súlyos tév eszméig ('paranoiapiramis'). Garety és Freeman [18] nyomán

telte a viselkedést, de afelé közelített a kérdőíves lakossági felmérések helyett. Azt is jelezte, hogy szignifikáns mértékben ilyen módszerrel is tetten érhető a gyanakvó/ bizalmatlan magatartás az átlagpopulációban [45].

Folytatván munkájukat, egy másik vizsgálatban célként azt jelölték meg, hogy alacsony, közepes és magas paranoiditású csoportok validálása virtuális valóság szimulációs módszerrel mennyire végezhető el. Emiatt alacsony (nem klinikai) paranoiás, magas nem klinikai paranoiás, üldöztetéses téveszméjü (doxasma, klinikai szintú) személyeket válogattak be, 30-30 föt csoportonként. Azt az eredmény kapták, hogy virtuális valóság helyzetben az üldöztetéses tartalmak korreláltak a pszichometriával, és a pszichés jellemzók (például interperszonális érzékenység) dózis-hatás összefüggést mutattak a paranoia súlyosságával. Arra a konklúzióra jutottak, hogy átlagpopulációban a paranoiára egy spektrum jelleg jellemző, a persecutoros gondolatok klinikai csoportokon kívül is előfordulnak, illetve összefüggnek egyéb pszichés jellemzőkkel (szorongás, aggodalom, érzékenység, depresszió, döntéshozatal, pszichotraumatizáció) [46]. A virtuális valóság laboratóriumi technikát kontrollált és randomizált vizsgálati elrendezésben kognitív pszichoterápiás módszerrel kombinálva (virtuális valóság kognitív terápia) csökkenés volt megfigyelhető a téveszmés meggyőződés mértékében, tehát a kezelés javította az állapotot [47].

\section{Lehet-e értelme a paranoiditásnak?}

Természetesen a túlzott gyanakvás és bizalmatlanság megölheti a társas kapcsolatokat, az egyént a társadalom kiközösítettjévé teheti és diszkrimináció, stigmatizáció elszenvedőjévé a paranoid gondolatokkal terhes létből adódó szubjektív szenvedés mellett. Ott van viszont földünkön a különféle társadalmakban világszerte bekövetkezett tragédiák sorozata (elég csak a 2001. szeptember 
11-ei terrortámadást említeni), hogy belássuk: bizonyos mértékű óvatosság, akár gyanakvás nem árt, sôt éppenséggel az egyén (és emberiség) érdekét és alkalmazkodását szolgálja.

Nem kell csak történelemrengető példákat említeni. Egyre inkább az szưrhető le a tudományos kutatások eredményeiből, hogy az enyhén paranoid beállítódás akár hasznos is lehet. Az üzleti világban uralkodó volt az a nézet, hogy a bizalom erőt jelent. Az újabb kutatások tükrében ez csak bizonyos fokig érvényes, túlzásba vitele veszélyes naivitás. Régi elv volt a vállalati menedzsmentben, hogy a bizalom a szervezet szupererôs ragasztója és a vezetési stílust is ez kell, hogy meghatározza. A bizalom és kooperáció több évtizedes szociálpszichológiai kutatásai szerint viszont úgy tûnik, hogy - a veszteségek ellenére - a mértéktartó bizalmatlanság inkább kifizetődő [48]. Az óvatosan, okosan körültekintő enyhe gyanakvásnak ('prudens paranoia') tehát nagyon is értelme lehet.

Anyagi támogatás: A közlemény elkészítése és az ahhoz kapcsolódó kutató- és irodalmi munka anyagi támogatásban nem részesült.

A cikk végleges változatát a szerző elolvasta és jóváhagyta.

Érdekeltségek: A szerzőnek nincsenek érdekeltségei.

\section{Köszönetnyilvánítás}

Köszönetemet fejezem ki Álmos Péternek, aki kutatómunkával kiderítette, hogy a Fregoli-szindrómának milyen köze lehet a fakeretből és zsinórokból összeállított, mennyezetre erősíthető, csigaberendezéssel fel- és lehúzható, 'fregoli’ nevú ruhaszárító szerkezethez. (Blau Jónás találmánya 1900-ban, aki az akkor éppen a Városligetben fellépó átváltozó múvész, Leopoldo Fregoli után adta a nevet a szerkezetnek.)

\section{Irodalom}

[1] Selye, H.: A syndrome produced by diverse nocuous agents. Nature, 1936, 138(3479), 32.

[2] Friedman, V. A.: The Zaporozhian letter to the Turkish Sultan: Historical commentary and linguistic analysis. Slavica Hierosolymitana, 1978, 2, 25-38.

[3] Freud, S.: Psychoanalytische Bemerkungen über einen autobiog raphisch beschriebenen Fall von Paranoia. In: Jahrbuch für psychoanalytische und psychopathologische Forschungen. III. 1. Hälfte. Franz Deuticke, Leipzig/Wien, 1911.

[4] Bell, V., Halligan, P. W., Ellis, H. D.: Explaining delusions: a cognitive perspective. Trends Cogn. Sci., 2006, 10(5), 219-226.

[5] Kapur, S., Mizrahi, R., Li, M.: From dopamine to salience to psychosis - linking biology, pharmacology and phenomenology of psychosis. Schizophr. Res., 2005, 79(1), 59-68.

[6] King, R., Barchas, J. D., Huberman, B. A.: Chaotic behavior in dopamine neurodynamics. Proc. Natl. Acad. Sci. U.S.A., 1984, 81(4), 1244-1247.

[7] Patru, M. C., Reser, D. H.: A new perspective on delusional states - evidence for claustrum involvement. Front. Psychiatry, $2015,6,158$.
[8] Brent, B. K., Coombs, G., Keshavanet, M. S., et al.: Subclinical delusional thinking predicts lateral temporal cortex responses during social reflection. Soc. Cogn. Affect. Neurosci., 2014, 9(3), 273-282.

[9] Rodier, M., Prévost, M., Renoult, L., et al.: Healthy people with delusional ideation change their mind with conviction. Psychiatry Res., 2011, 189(3), 433-439.

[10] Ross, R. M., McCay, R., Coltheart, M., et al.: Jumping to conclusions about the beads task? A meta-analysis of delusional ideation and data-gathering. Schizophr. Bull., 2015, 4l(5), 1183-1191.

[11] Cameron, N. A.: Personality development and psychopathology - A dynamic approach. Houghton Mifflin, Boston, 1963.

[12] Janka, Z.: Serotonin dysfunctions and the "seven deadly sins". [Szerotonin diszfunkciók a hét fő́bün hátterében.] Clin. Neurosci./Ideggy. Szle, 2003, 56(11-12), 376-385. [Hungarian]

[13] Linszen, M. M., Brouwer, R. M., Heringa, S. M., et al.: Increased risk of psychosis in patients with hearing impairment: Review and meta-analyses. Neurosci. Biobehav. Rev., 2016, 62, 1-20.

[14] Bentall, R. P., Taylor, J. L.: Psychological processes and paranoia: implications for forensic behavioural science. Behav. Sci. Law, 2006, 24(3), 277-294.

[15] Janssen, I., Hanssen, M., Bak, M., et al.: Discrimination and delusional ideation. Br. J. Psychiatry, 2003, 182(1), 71-76.

[16] Oh, H., Yang, L. H., Anglin, D. M., et al.: Perceived discrimination and psychotic experiences across multiple ethnic groups in the United States. Schizophr. Res., 2014, 157(1-3), 259-265.

[17] Lien, Y. J., Kao, Y. C., Liu, Y. P., et al.: Relationships of perceived public stigma of mental illness and psychosis-like experiences in a non-clinical population sample. Soc. Psychiatry Psychiatr. Epidemiol., 2015, 50(2), 289-298.

[18] Garety, P. A., Freeman, D.: The past and future of delusions research: from the inexplicable to the treatable. Br. J. Psychiatry, 2013, 203(5), 327-333.

[19] Conrad, K.: Die beginnende Schizophrenie: Versuch einer Gestaltanalyse des Wahns. Thieme Verlag, Stuttgart, 1958.

[20] Tényi, T.: Rare psychiatric symptoms and syndromes. [Ritka pszichiátriai tünetek és szindrómák.] Animula Kiadó, Budapest, 2009. [Hungarian]

[21] Gerevich, J., Ungvari, G. S.: The description of the litigious querulant: Heinrich von Kleist's novella Michael Koblhaas. Psychopathology, 2015, 48(2), 79-83.

[22] Benedict, R.: Patterns of culture. Houghton Mifflin, Boston, 1934.

[23] Szilárd, J., Janka, Z.: Elements of social psychology. University Medical School Press, Szeged, 1986.

[24] Mead, M.: Sex and temperament in three primitive societies. Morrow, New York, 1935

[25] Lehmann, H. E.: Unusual psychiatric disorders, atypical psychoses, and brief reactive psychoses. In: Kaplan, H. I., Freedman, A. M., Sadock, B. J. (eds.): Comprehensive textbook of psychiatry. Third edition. Williams \& Wilkins, Baltimore/London, 1980, Vol. 2, pp. 1986-2002.

[26] Paniagua, F. A.: Culture-bound syndromes, cultural variations, and psychopathology. In: Cuéllar, I., Paniagua, F. A. (eds.): Handbook of multicultural mental health: Assessment and treatment of diverse populations. Academic Press, New York, 2000, pp. 140-141.

[27] Strauss, J. S.: Hallucinations and delusions as points on continua function. Arch. Gen. Psychiatry, 1969, 21(5), 581-586.

[28] Peters, E. R., Joseph, S. A., Garety, P. A.: Measurement of delusional ideation in the normal population: introducing the PDI (Peters et al. Delusions Inventory). Schizophr. Bull., 1999, 25(3), 553-576.

[29] Peters, E., Joseph, S., Day, S., et al.: Measuring delusional ideation: the 21 -item Peters et al. Delusions Inventory (PDI). Schizophr. Bull., 2004, 30(4), 1005-1022.

[30] Verdoux, H., Maurice-Tison, S., Gay, B., et al.: A survey of delusional ideation in primary-care patients. Psychol. Med., 1998, $28(1), 127-134$. 
[31] Verdoux, H., van Os, J.: Psychotic symptoms in non-clinical populations and the continuum of psychosis. Schizophr. Res., 2002, 54(1-2), 59-65.

[32] López-Ilundain, J. M., Pérez-Nievas, E., Otero, M., et al.: Peters delusions inventory in Spanish general population: internal reliability, factor structure and association with demographic variables (dimensionality of delusional ideation). Actas Esp. Psiquiatr., 2006, 34(2), 94-104.

[33] Forsell, צ., Henderson, A. S.: Epidemiology of paranoid symptoms in an elderly population. Br. J. Psychiatry, 1998, 172, 429-432.

[34] Lundberg, P., Cantor-Graae, E., Kabakyenga, J., et al.: Prevalence of delusional ideation in a district in southwestern Uganda. Schizophr. Res., 2004, 71(1), 27-34

[35] Freeman, D.: Delusions in the nonclinical population. Curr. Psychiatry Rep., 2006, 8(3), 191-204.

[36] Sharifi, V., Bakbshaie, J., Hatmi, Z., et al.: Self-reported psychotic symptoms in the general population: Correlates in an Iranian urban area. Psychopathology, 2012, 45(6), 374-380.

[37] Prochwicz, K., Gawęda, E.: The Polish version of the Peters et al. Delusions Inventory: factor analysis, reliability and the prevalence of delusion-like experiences in the Polish population. Psychiatr. Pol., 2015, 49(6), 1203-1222.

[38] Martin, J. A., Penn, D. L.: Social cognition and subclinical paranoid ideation. Br. J. Clin. Psychol., 2001, 40(3), 261-265.

[39] Ellett, L., Lopes, B., Chadwick, P.: Paranoia in a nonclinical population of college students. J. Nerv. Ment. Dis., 2003, 191(7), 425-430.

[40] Fonseca-Pedrero, E., Paino, M., Santarén-Rosell, M., et al.: Psychometric properties of the Peters et al. Delusions Inventory 21 in college students. Compr. Psychiatry, 2012, 53(6), 893-899.
[41] Freeman, D., Garety, P. A., Bebbington, P. E., et al.: Psychological investigation of the structure of paranoia in a non-clinical population. Br. J. Psychiatry, 2005, 186(5), 427-435.

[42] Zawadzki, J. A., Woodward, T. S., Sokolowski, H. M., et al.: Cognitive factors associated with subclinical delusional ideation in the general population. Psychiatry Res., 2012, 197(3), 345-349.

[43] Varghese, D., Wray, N. R., Scott, J. G., et al.: The heritability of delusional-like experiences. Acta Psychiatr. Scand., 2013, 127(1), 48-52.

[44] Pechey, R., Halligan, P.: The prevalence of delusion-like beliefs relative to sociocultural beliefs in the general population. Psychopathology, 2011, 44(2), 106-115.

[45] Freeman, D., Pugh, K., Antley, A., et al.: Virtual reality study of paranoid thinking in the general population. Br. J. Psychiatry, 2008, 192(4), 258-263.

[46] Freeman, D., Pugh, K., Vorontsova, N., et al.: Testing the continuum of delusional beliefs: An experimental study using virtual reality. J. Abnorm. Psychol., 2010, 119(1), 83-92.

[47] Freeman, D., Bradley, J., Antley, A., et al.: Virtual reality in the treatment of persecutory delusions: randomised controlled experimental study testing how to reduce delusional conviction. Br. J. Psychiatry, 2016, 209(1), 62-67.

[48] Kramer, R. M.: When paranoia makes sense. Harv. Bus. Rev., $2002,80(7), 62-69$

(Janka Zoltán dr., Szeged, Kálvária sgt. 57., 6720 e-mail: janka.zoltan@med.u-szeged.hu)

\section{PÁLYÁZAT}

A Prof. Dr. Romics László Akadémikus Emlékére Alapítvány pályázatot hirdet Magyarországon dolgozó, magyar állampolgárságú, 40 éven aluli orvosok és orvosbiológiai kutatással foglalkozó személyek számára. A nyertes pályázó(k) között $500000 \mathrm{Ft}$ alapítványi adomány kerül kiosztásra.

A pályázat célja: a klinikai gyógyítás vagy orvosi tudományos kutatás területén dolgozók kiemelkedő tudományos tevékenységének elismerése.

Előnyt élveznek azok a pályázók, akik az alapítvány névadójának munkásságát folytatva cardiovascularis és anyagcsere-betegségek területéről nyújtanak be pályázatot.

A pályázatot természetes személy, saját nevében, magyar nyelven nyújthatja be, a pályázati anyag ábrák nélkül maximum 15000 leütés (karakter) terjedelmü lehet. A pályázathoz mellékelni kell egy rövid szakmai életrajzot.

A pályázat benyújtásának határideje: 2017. január 31. (elbírálásának határideje: 2017. április 30.)

A pályázatot a palyazat@romicsalapitvany.hu e-mail címre pdf formátumban kell benyújtani.

A pályázat benyújtását saját kézzel aláírt és dátummal ellátott levélben kell bejelenteni az alapítvány titkárának címezve (a borítékra írandó cím: dr. Dudás Márta, 1461 Budapest, Pf 62.) könyvelt (ajánlott) küldeményben, mert ezen bejelentés alapján válik hitelessé a pályázat.

Az alapítvány adatairól, müködéséről a www.romicsalapitvany.hu honlapon található információ. 